\title{
10. Square pegs and round holes: Shrinking protections for unpaid interns under the Fair Labor Standards $\operatorname{Act}^{1}$
}

\section{James J. Brudney}

\subsection{INTRODUCTION}

Since 2011 in the United States, there have been close to 1 million unpaid interns among the university population during any given year. ${ }^{2}$ Although many if not most are working at for-profit companies, their right to compensation under the Fair Labor Standards Act (FLSA) ${ }^{3}$ has been denied or seriously questioned under standards set out by the federal courts of appeal. Yet the FLSA offers the broadest definition of 'employ' in all federal law, along with detailed exemptions requiring a reduced but actual wage payment for 'apprentices', 'learners' and 'students'. ${ }^{4}$ And Congress, when enacting the FLSA in 1938 and amending it in subsequent decades, has expressed a goal of preventing evasion of minimum wage requirements under the guise of such exemptions. How have the law's protections been eroded in such a way? That is the principal question this chapter sets out to answer.

\footnotetext{
1 I thank Jennifer Gordon and David Weil for very helpful comments on an earlier draft, Janet Kearney and Jeff Irwin for excellent research assistance, and Fordham Law School for generous financial support. This chapter is current as of September 2020.

2 Precise figures on the number of unpaid interns are not available. Ross Perlin's path-breaking book Intern Nation: How to Earn Nothing and Learn Little in the Brave New Economy (Verso 2011) concluded that as many as 75 per cent of the 9.5 million students then attending four-year colleges and universities 'undertake at least one internship before they graduate': ibid xiv. Since 2011, attendance at these institutions has increased to almost 11 million. Between 40 per cent and 50 per cent of internships were unpaid between 2011 and 2018, with a modest decline occurring over that period.

29 USC s $201 \mathrm{ff}$.

4 See 29 USC s 203(g) (““employ” includes to suffer or permit to work'); s 214(a), (b) (setting forth exemptions).
} 
All statutes are meant to apply over time to unforeseen circumstances. Under our canons of construction, remedial statutes such as those protecting civil rights or labour standards are to be liberally construed, meaning interpreted expansively in response to new situations. At the same time, private employers regulated under comprehensive workplace statutes often maintain that enforcement will compromise established or preferred business policies. As regards unpaid internships, these policies reflect an implicit arrangement involving commercial enterprises and universities. In recent decades, private employers - often working with educational institutions - have contended that internships are an important form of training and socialization into the world of white-collar work, and as such they can justifiably be unpaid.

Legal standards under the FLSA were, until recently, fairly clear. They had been consistently articulated by the agency from 1938, as applied through a leading Supreme Court decision in 1947 and a series of Labor Department Interpretive Bulletins, opinion letters and related agency pronouncements over many decades, emanating from both Democratic and Republican administrations. Pursuant to this confluence of enacted text, agency application and Supreme Court analysis, unpaid internships at for-profit employers were permissible only if they were part of a prescribed educational or training course that offered close employer supervision of the educational experience, with no displacement of regular employees and no immediate employer advantage derived from intern performance. ${ }^{5}$ However, this long-standing approach has been superseded by an ad hoc balancing test adopted by numerous courts of appeal in the past decade. The prevalence of the new primary beneficiary approach has made it considerably easier for for-profit employers to establish and maintain unpaid internships.

This chapter's main argument is that the new balancing test is in tension with the text, legislative history and long-standing agency application of the Act. As the bright-line approach - developed over decades to protect basic minimum rights to compensation for work performed - has been replaced by a balancing test permitting far more judicial discretion, unpaid internships have become easier to justify under the FLSA. Unpaid internships are also

5 The FLSA separately provides for unpaid 'volunteer' activities applicable to internships at public agencies. See 29 USC s 203(e)(4); 29 CFR s 553.101-4. The Wage $\&$ Hour Division of the Department of Labor (DOL) has opined that, for both public agencies and non-profits (in contrast to for-profit employers), volunteers may displace paid employees and also may provide these organizations with an immediate advantage from the interns' work. The FLSA could be applied more rigorously to protect interns in non-profit settings: see David C Yamada, 'The Legal and Social Movement against Unpaid Internships' (2016) 8 NEULJ 357, 375-8. This chapter, however, addresses only the legal and policy aspects of for-profit internships. 
contestable as a matter of policy. The asserted benefits of internships include résumé enhancement, networking opportunities and training. But available data indicates that these benefits are realized to a considerably greater degree by paid rather than unpaid interns. And any benefits for unpaid interns are offset, if not outweighed, by various individual and social costs: lack of protection under anti-discrimination laws for unpaid intern non-employees; the socio-economic impact on student populations when access to unpaid internships is a function of family wealth; and employers' ability to substitute unpaid interns for regular employees receiving decent wages. Still, whatever the policy ramifications, the FLSA was enacted to prevent the undermining of basic worker protections.

\subsection{UNPAID INTERNS AND THE LAW}

\subsubsection{FLSA 1938 Text and Initial Context}

Although a number of states had enacted minimum wage laws by the 1920s, the Supreme Court in 1923 held that these laws unconstitutionally interfered with employers' ability to freely negotiate wage contracts with their employees. ${ }^{6}$ The Roosevelt Administration made the first attempt to establish a national minimum wage in 1933, but the National Industrial Recovery Act was ruled unconstitutional by the Supreme Court in 1935. ${ }^{7}$ After President Roosevelt's overwhelming re-election in 1936, he first pursued legislation to reform Supreme Court membership while also supporting a new law to provide for minimum wage and overtime protection. ${ }^{8}$ The bill that became the Fair Labor Standards Act was introduced in the Senate in May 1937, and was signed into law in June 1938. ${ }^{9}$ The original bill gave broad discretion to a 'Fair

6 Adkins v Children's Hospital 261 US 525 (1923). See Frank T DeVyver, 'Regulation of Wages and Hours Prior to 1938' (1939) 6 Law \& Contemp Prob 323, 327.

ALA Schechter Poultry Corp v United States 295 US 495 (1935).

8 See John S Forsythe, 'Legislative History of the Fair Labor Standards Act' (1939) 6 Law \& Contemp Prob 464, 465-6; Delbert Clark, 'Unions Drive for New Labor Laws' New York Times (New York, 10 January 1937); 'Good Form' Time Magazine (11 January 1937) 13. The Court altered its position in late March 1937, upholding the constitutionality of a state minimum wage law for the first time: West Coast Hotel Co v Parrish 300 US 379 (1937).

9 See Forsythe (n 8) 466-73. The 1938 minimum wage law covered 'employees engaged in interstate commerce or in the production of goods for interstate commerce'. Amendments in 1961 and 1966 extended the federal minimum wage law to employees in retail and service enterprises, state and local government employees, and other areas of the economy. 
Labor Standards Board' to establish exemptions at 'lower than applicable' wage levels for the employment of learners and apprentices. ${ }^{10}$ The final bill substantially narrowed that discretion. As enacted, the FLSA directed the Wage \& Hour Administrator to provide 'by regulation or by orders' for the employment of learners and of apprentices, under special certificates issued by the Administrator, 'to the extent necessary in order to prevent curtailment of [their] opportunities for employment' at 'such wages lower than the [statutory] minimum wage and subject to such limitations as to time, number, proportion, and length of service' as the Administrator prescribed. ${ }^{11}$ For current purposes, there are certain key takeaways from this text specifying exemptions for learners and apprentices: (1) they are to be paid; (2) their lower rates of pay are justified by the need to prevent curtailment of their own opportunities for employment; and (3) they are covered by special certificates as prescribed by the Administrator.

Congress added a parallel exemption in 1961, also based on preventing curtailment of opportunities for employment for 'full-time students outside of their school hours in any retail or service establishments'. ${ }^{12}$ Congress in 1966 expanded this exemption to cover full-time students without regard to their school hours (in compliance with child labour laws), and extended coverage to students employed in agriculture and at institutions of higher education where they are enrolled.

The relatively sparse relevant legislative history addressing the 1938 exemptions indicates that 'learners' were meant to be included as part of the term 'employee'. This is reflected in floor statements and hearing testimony noting the need to prevent employers from evading minimum wage provisions by utilizing 'learners' ${ }^{13}$ and also by defeat of a House amendment proposing to exclude 'beginners and apprentices' from the Act's coverage for an initial period. $^{14}$

The Administrator's initial regulations on the 1938 law reinforced the narrowness of the learner and apprentice exemptions. Employers had to apply

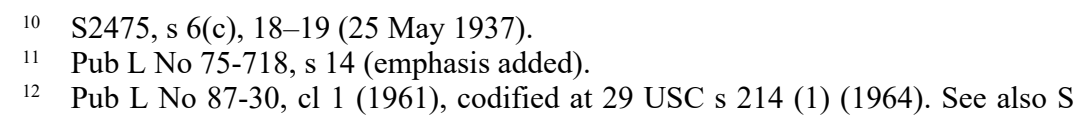
Rep 87-145, 50-51 ('This section provides for employment (as in the case of learners and apprentices under present law) of full-time students ... in retail or service establishments in jobs not of the type ordinarily given to a full-time employee'); HR Rep 87-75, 11 .

13 Joint Hearings on S2475 and HR 7200, 75th Cong, 1st Sess 1937, 37, 38, 44 (statement of Assistant Attorney General Robert Jackson); 83 Cong Rec 7309 (23 May 1938) (remarks of Rep Fitzgerald).

1483 Cong Rec 7389, 7391, 7393 (24 May 1938) (consideration and rejection of amendment offered by Rep Taylor). 
to the Labor Department for approval to employ learners at the lower rate; propose a specific lower hourly pay rate and explain why learners should be receiving that reduced pay rate; and carry the burden of demonstrating at a hearing that paying the applicable minimum wage 'will curtail employment opportunities for learners in the occupation'.$^{15}$ In denying the first two applications for learner exemptions, the Administrator concluded that for one job the employer's request for a 90-day learning period was excessive as the training could be completed in a week, and for the second type of job the work was easily learned and there was a large available supply of experienced workers. ${ }^{16}$ In summary, the detailed and explicit regulatory approach adopted by the Administrator, closely tracking the statutory text, conveyed that these exemptions were meant to provide some level of compensation for learners and apprentices, but that, even so, they would be narrowly construed to prevent exploitation by employers who wished to avoid paying regular minimum wage rates. ${ }^{17}$

\subsubsection{The Supreme Court in 1947: Walling v Portland Terminal Co}

Against this background, the Supreme Court in 1947 decided its first case raising the possibility that persons being trained for jobs with an employer might be exempted from the Act altogether as non-employees rather than exempted from the full wage provisions as learners or apprentices. In Walling $v$ Portland Terminal $\mathrm{Co},{ }^{18}$ the railroad company offered a seven- to eight-day course to applicants for the position of yard brakeman, in which each applicant was supervised by regular yard crew, learning tasks through observation and eventually by doing the actual work under close scrutiny. While the applicant was involved in training needed to acquire skills for a full-time job, the Court made clear that his activities 'do not displace any of the regular employees'

15 Wage and Hour Regulation 1939 pts 522.4, 522.5, 522.7. Similar requirements were imposed for persons seeking to employ apprentices: ibid pts 521, 521.1.

16 Denial of Applications for Learner Exemptions involving pecan shellers and silk throwers, W\&H Reference Manual (1939) 84. Further, when interpreting the comparably phrased exemption for 'messengers employed exclusively in delivering letters and messages' in the 1938 statute, the Administrator rejected an exemption application from Western Union once it was established that the messengers performed separate duties in addition to delivering messages. The Administrator noted that this exemption would give the company a competitive advantage in those separate areas from paying a sub-minimum wage: W\&H Reference Manual (1939) 85-9 (Administrator's Decision on Western Union Appeal affirming report and findings of Presiding Officer).

17 See Frank E Cooper, 'The Coverage of the Fair Labor Standards Act and Other Problems in its Interpretation' (1939) 6 Law \& Contemp Prob 333, 334, 343-4.

18330 US 148 (1947). 
and his work 'does not expedite the company's business, but may, and sometimes does, actually retard it' ${ }^{19}$

The Court recognized Congress's purpose of avoiding a 'blanket exemption' of trainees from the Act's wage provisions by allowing for '[f]lexibility of wage rates under the safeguard of administrative permits'. But notwithstanding the Act's broad definitions of 'employ' and 'employee', those definitions do not make 'a person whose work serves only his own interest an employee of another person who gives him aid and instruction' ${ }^{20}$ Accepting the 'unchallenged findings' that 'the railroads receive no "immediate advantage" from any work done by the trainees', the Court concluded that these trainees were not employees under the Act. ${ }^{21}$

This is not to say that the railroads initiated this training out of philanthropic motives. They considered the programme helpful in identifying future employees from among individuals who participated. Still, they reaped no 'immediate advantage' during the course of the programme itself. In this regard, the Court reasoned that, had the trainees taken similar instruction at a vocational school unconnected to the railroad, they would not be deemed employees of the school. Nor could they be regarded as employees of the railroad simply because upon graduation they might be hired by the railroads. The Court remained keenly aware of the possibility of evasion of the minimum wage law's letter or spirit if employers accepted the services of learners at substandard pay and without permits from the Administrator. But it determined that the instant set of factual circumstances did not raise that threat.

\subsubsection{The Administrator's Consistent Application of the Supreme Court Approach}

In the decades following Portland Terminal, the Administrator received numerous fact-specific inquiries from employers and educational institutions concerning whether students, trainees or interns are entirely exempt from the FLSA. In responding through opinion letters, the Administrator from at least the early 1960s relied on six general criteria derived from Portland Terminal,

19 Ibid 149-50. The respondent's brief in Portland Terminal relied heavily on the facts as found below, emphasizing that the trainee 'is always an extra and unnecessary man [who] does not aid the work of a yard crew but rather impedes it and slows it down': Brief for Respondent, 5.

20 Ibid 152 (emphasis added).

$21 \quad$ Ibid 153 (emphasis added). 
and made clear that students, trainees or interns are not employees only if all six of the criteria apply. These six criteria are:

1. The training, even though it includes actual operation of the facilities of the employer, is similar to that which would be given in a vocational school.

2. The training is for the benefit of the trainees or students.

3. The trainees or students do not displace regular employees, but work under their close supervision.

4. The employer that provides the training derives no immediate advantages from the activities of the trainees or students, and on occasion the employer's operations may be impeded.

5. The trainees or students are not necessarily entitled to a job at the conclusion of the training period.

6. The employer and the trainees or students understand that the trainees or students are not entitled to wages for the time spent in training. ${ }^{22}$

In applying these six criteria to factual settings, the Administrator reached varying determinations. Students required to engage in a particular number of hours of on-the-job training or work experience as a prescribed part of a specialized educational course were not considered employees of the firms where the training took place. ${ }^{23}$ On the other hand, participants in education or training programmes were considered employees where they engaged in work that was needed to help operate a facility (to that extent displacing regular employees), or where products that vocational students generated enabled the cooperating firm to constrain job opportunities for regular employees (again displacement), or where the training programme competed to any extent with other establishments in an industry or trade (so that the employer derived an immediate advantage). ${ }^{24}$

22 See Opinion Letter of 5 September 2002, 2002 WL 32406598; Opinion Letter of 8 May 1996, 1996 WL 1031777; Opinion Letter of 27 March 1986, Wages-Hours 89-90 CCH-WH para 31,831; Opinion Letter of 19 October 1961, Wages-Hours 61-66 CCH-WH para 30,558.

23 Opinion Letter of 31 March 1970, Wages-Hours 69-73 CCH-WH para 30,630 (90-100 hours required by an interior design department at a state university); Opinion Letter of 18 July 1967, Wages-Hours 66-69 CCH-WH para 30,628 (hours required by a course to become a certified laboratory assistant).

24 Opinion Letter of 17 January 1986, Wages-Hours 89-90 CCH-WH para 31,749 (participants in a food service training programme); Opinion Letter of 22 February 1974 Wages-Hours 73-78 CCH-WH para 30,911 (vocational school trainees producing glove inserts); Opinion Letter of 9 June 1969, Wages-Hours 69-73 CCH-WH para 30,548 (military personnel being trained to return to civilian life for any week when they are individually engaged in or producing goods for interstate commerce). On still 
Although many of the Administrator's decisions dealt with vocational training broadly analogous to that which was at issue in Portland Terminal, some responded to inquiries involving white-collar internships. When on-site work experience is part of a required university or professional/white-collar vocational curriculum, or is part of a clinical internship or externship course offered at all professional schools of this type, even if not required, then the work experience is unlikely to give rise to an employment relationship. ${ }^{25}$ The Administrator distinguished the educationally prescribed or system-wide for-credit aspects of the work experience from settings where similar job-related assignments were termed an 'internship' in a post-graduation setting. ${ }^{26}$

Moreover, the Administrator was troubled by other white-collar internship or experience-based programmes that occurred in an educational setting. For instance, an internship of 7-10 hours a week where students perform the work of a field marketing representative on campus - responsible for collecting data, conducting surveys and utilizing online chat rooms while wearing company logo clothing - may well confer an immediate benefit on the employer, and students may not be closely supervised during their work. These aspects would violate two of the Portland Terminal criteria. ${ }^{27}$ Third-year law students who serve as teaching assistants to law professors, although viewed as an educational experience, seemed likely to be deemed employees under the FLSA in the 1960 s, as they would be today. ${ }^{28}$ In short, Administrator determinations

other occasions, the Administrator declined to make a specific determination because the information presented by the inquirer was insufficient to decide whether all six factors had been met. See eg Opinion Letter of 5 September 2002 (n 22); Opinion Letter of 8 May 1996 (n 22); Opinion Letter of 13 March 1995, 1995 WL 1032473.

25 Opinion Letter of 7 July 1977, Wages-Hours 73-78 CCH-WH para 31,122 (pharmacy school students engaged in 16 hours weekly work experience at participating hospital or community pharmacies as part of for-credit clinical internship and externship course, together with four hours of weekly classroom lectures and laboratory work; while the course is optional, it is offered at all 72 pharmacy schools in the country); Opinion Letter of 31 March 1970 (n 23) (university degree in interior design requires that rising seniors experience $90-100$ hours of practical interior design work under supervision of interior design firm); Opinion Letter of 18 July 1967 (n 23) (student in training to become certified laboratory assistant engages in work experience at hospital as a required part of the curriculum; student receives stipend or allowance for subsistence which is not considered wages establishing an employment relationship).

26 Opinion Letter of 7 July 1977 (n 25) (Administrator emphasized that, unlike required undergraduate course work experience, post-graduation internships at pharmacies 'certainly' would 'give rise to employment relationships between the intern and the employing pharmacy').

27 Opinion Letter of 17 May 2004, FLSA2004-5NA.

28 Opinion Letter of 13 September 1967, Wages-Hours 66-69 CCH-WH para 30,641 . This is a separate inquiry from whether teaching assistants are employees under 
from the 1960s into the 2000s feature various applications of the Portland Terminal factors in white-collar settings.

Administrator opinion letters invoking Portland Terminal have been issued under Democratic and Republican administrations for more than half a century. ${ }^{29}$ Although they are not agency pronouncements with the force of law, such as notice and comment rules, their consistency in structure and thoroughness of exposition qualify them for some degree of deference under the Skidmore doctrine. ${ }^{30}$ A review of relevant federal court decisions suggests that there was greater respect for the Administrator's approach in the period up to the early 1990s, but little agreement with that approach since about 2011.

\subsubsection{Lower Federal Courts from the 1970s to the Early 1990s}

Lower court cases during this period recognized the importance of the six Portland Terminal criteria, but began articulating more of an 'economic reality' approach when applying the six criteria, by assessing which party (trainees/students or employers) received the bulk of the benefit. ${ }^{31}$ When the training was short term and on-the-job, some courts pointed to the limited and narrow kinds of learning that took place, while also emphasizing whether trainees performed tasks or functions that provided immediate benefit to the employer's business. ${ }^{32}$ However, when the training consisted of a longer-term vocational course provided by the employer, the fact that such a course produced a labour pool of potential employees did not by itself create the 'immediate advantage' to which Portland Terminal referred. ${ }^{33}$

Courts tended to consider the 'no immediate advantage' factor in more depth for longer-term training. One court examined evidence to determine that

the National Labor Relations Act, which has a more elaborated statutory definition of 'employee'. See Trustees of Columbia University 364 NLRB No 90 (2016).

29 The author was able to retrieve 17 Administrator opinion letters addressing the Portland Terminal factors, dating from the early 1960s to 2013. Of the 13 letters cited in nn 22-28, seven are from Democratic administrations and six from Republican administrations.

$30 \quad$ Skidmore v Swift \& Co 323 US 134 (1944); United States v Mead Corp 533 US 218 (2001). See Solis v Laurelbrook Sanitarium and School 642 F 3d 518, 525 (6th Cir, 2011) (reviewing varying circuit court rulings as to appropriate deference due to DOL's six-part test).

31 See eg McLaughlin v Ensley 877 F 2d 1207, 1209 (4th Cir, 1989); Donovan v American Airlines 686 F 2d 267, 272 (5th Cir, 1982); Marshall v Baptist Hospital 473 F Supp 465, 476 (D Tenn, 1979).

32 See eg McLaughlin v Ensley (n 31) 1210; Bailey v Pilots' Association for Bay and River Delaware 406 F Supp 1302, 1307 (ED Pa, 1976).

33 Donovan (n 31) 272. 
long-term trainees whose course required time in the field did not assume the duties or perform any key functions of the career employees who helped train them. ${ }^{34}$ And, in a situation where on-the-job training and outside class work were sufficiently distinct components, the court relied in part on the trainees being entitled to be paid for the productive work content of their activities though not for the classroom activities. ${ }^{35}$

Importantly, most courts closely analysed training courses to determine whether they taught skills and competencies that were employer-specific or 'fully fungible' so they could be utilized in other settings with minimal additional training. ${ }^{36}$ When the skills imparted were deemed valuable and transferrable, courts concluded that the immediate benefit flowed to the trainees or students. ${ }^{37}$ However, if the courses were not well supervised, trainees did not receive adequate orientation, they were restricted to performing one or two procedures, or they spent substantial portions of time on routine activities of at best peripheral educational value, then courts found the course conferred minimal or no benefit on trainees and instead delivered the bulk of benefits to the employer. ${ }^{38}$

\subsubsection{Federal Appeals Courts in Recent Years: The Primary Beneficiary Approach}

Since 2011, appeals courts in seven circuits have addressed the issue of whether students or trainees should be considered workers under the FLSA. In two instances, the courts invoked the six Portland Terminal criteria, articulating an economic reality approach similar to the decisions described from prior decades. ${ }^{39}$ These courts applied the six factors by focusing primarily on whether the skills and training acquired in an extended vocational course were transferrable, and whether the course provider (a for-profit enterprise) derived

\footnotetext{
34 Reich v Parker Fire Protection District 992 F 2d 1023, 1028 (10th Cir, 1993) (ten-week training course at a firefighting academy).

35 Ballou v General Electric Co 433 F 2d 109, 111 (1st Cir, 1970) (40-hour-a-week training that includes work at GE plant and classwork at independent educational institutions).

36 Donovan (n 31) 270 (four- to five-week training course). See also Reich v Parker (n 34) 1027.

37 See eg Reich v Parker (n 34); Donovan (n 31).

38 Marshall v Baptist Hospital (n 31) 475-7 (two-year training course). See also McLaughlin v Ensley (n 31) 1209-10 (five-day course).

39 Nesbitt v FCNH Inc 908 F 3d 643, 647 (10th Cir, 2018); Harbourt v PPE Casino Resorts Maryland 820 F 3d 655, 660-61 (4th Cir, 2016), cf Hollins v Regency Corp 867 F 3d 830, 835-6 (7th Cir, 2017) (invoking Portland Terminal and the six factors while resolving the issue based on its own ad hoc analysis).
} 
immediate advantage from the training offered. In one case, an integrated classroom and clinical training course in massage therapy (where the clinical component included massages for members of the public at discounted rates) was held to be of primary if not exclusive benefit to the trainees rather than the facility operator. ${ }^{40}$ In the other case, trainees' allegations about a casino's 12-week training course for table dealers (that the training was tailored to the casino's specifications and not transferrable to work in other casinos) were found to confer immediate advantage on the casino and were 'either conceived or carried out in such a way as to violate ... the spirit of the minimum wage law'. ${ }^{41}$

\subsubsection{Analysing the primary beneficiary approach}

Four circuits have openly rejected the six Portland Terminal criteria that were applied for decades by the Department of Labor. These courts found the agency's approach 'a poor method for determining employee status in a training or educational setting' ${ }^{42}$ and inapposite for 'longer-term intensive modern internships that are required to obtain academic degrees and professional certification and licensure'. ${ }^{43}$ Instead, following the lead of the Second Circuit, they have invoked seven non-exhaustive factors, none of which carries presumptively special weight, to assess whether the student/trainee or the employer is the 'primary beneficiary' of the educational arrangement. ${ }^{44}$ The Second Circuit's list of seven factors ${ }^{45}$ tracks the agency's six factors in certain

$40 \quad$ Nesbitt (n 39) 645, 648. The court noted, but did not rely on, evidence that the school made no profit from the programme given its overhead and other operational costs. The Tenth Circuit stated that it was following the economic reality test from circuit precedent in Reich $v$ Parker (n 34) and declined to adopt the primary beneficiary test that had recently been articulated by the Second Circuit in Glatt $v$ Fox Searchlight Pictures Inc. 811 F 3d 528 (2016), discussed below. See Nesbitt (n 39) 647.

${ }_{41}$ Harbourt (n 39) 660-61 (quoting Portland Terminal (n 18) 153). The Fourth Circuit concluded that the facts alleged stated a claim under the FLSA and reversed the lower court's dismissal of the complaint: ibid 661.

42 Solis (n 30) 525.

43 Schumann v Collier Anesthesia, PA 803 F 3d 1199, 1211 (11th Cir, 2015).

44 Glatt v Fox Searchlight Pictures ( $\mathrm{n} 40$ ). The Second Circuit test was endorsed by the Eleventh Circuit in Schumann v Collier (n 43) 1211-12, and by the Ninth Circuit in Benjamin v B\&H Education Inc 877 F 3d 1139, 1147 (2017), which also identified the Solis court (Sixth Circuit) as adhering to this approach.

45 The seven factors in Glatt are identified in terms of 'the extent to which' each applies: (1) mutual understanding of no expected compensation; (2) provision of training similar to that provided in an educational environment; (3) links to a formal education programme such as receipt of academic credit; (4) correspondence to the academic calendar; (5) duration limited to the period of beneficial learning; (6) intern work complementing, rather than displacing, work of paid employees while providing significant 
particulars - notably that the training is similar to what would be provided in an educational environment; that the student/intern's work does not displace the work of paid employees; and that both employer and student/intern understand there is to be no compensation for time spent in training and also no expectation of a paid job at the conclusion of such training. ${ }^{46}$

At the same time, the new standard - which was subsequently adopted by the Trump Administration Labor Department ${ }^{47}$ - departs in notable respects from the long-standing Labor Department approach. First, it identifies as relevant various detailed aspects of the modern higher education process: whether the student/intern receives academic credit or their experience is integrated with other coursework; whether the internship corresponds to the academic calendar; and whether the duration of the internship is limited to a period of beneficial learning. These new factors can serve as constraints against abuse, but they are primarily formalistic and procedural rather than substantive. Also, while the circuit courts have maintained that these new factors were needed to bring the Portland Terminal approach into the modern era, the Administrator had long been sensitive to specific interactions between such extended training courses and receipt of academic credit as well as the integration of experiential learning in a curricular context. ${ }^{48}$

Of greater significance, the new 'primary beneficiary' standard removes a key substantive component of the Labor Department approach: that the employer providing the training derives no immediate advantage from the activities of the trainees or students. ${ }^{49}$ The 'no immediate advantage' factor was never understood to disqualify employers simply because they offer training. Identifying and helping to prepare a pool of potential or likely future employees is presumably the main reason most employers provide or underwrite the training courses in the first place. But what 'no immediate advantage' does accomplish is to focus the close attention of reviewing authorities (either the agency or courts) on whether employers benefit in more direct terms from the educational programme.

This immediate benefit to employers could derive from work performed by 'students/interns' during the course of the programme, work that does not technically displace other employees but that still enriches the employer while

educational benefits; and (7) mutual understanding of no entitlement to a paid job at the end of the internship.

46 Compare factors $1,3,5$ and 6 of the agency approach above (text at $\mathrm{n} 22$ ) with factors 1, 2, 6 and 7 of the Second Circuit test.

47 See DOL Field Assistance Bulletin No 2018-2, 5 January 2018.

48 See previous discussion of Administrator letters.

49 Listed as the fourth Portland Terminal factor by the Administrator, also noting that 'on occasion the employer's operations may actually be impeded'. 
failing to compensate the students. A remarkable illustration is the decision in Solis v Laurelbrook Sanitarium and School. ${ }^{50}$ Once the Court determined that students rather than the sanatorium were the 'primary beneficiaries' of the school's practical training component, it discounted as 'offset in various ways' the considerable economic value the school realized from countless hours of uncompensated activities required of students. ${ }^{51}$ Another example involves menial tasks performed by student interns going well beyond the licensure-related work experience that justified their status as non-employees. One court suggested that, by assigning them tasks such as receptionists, cleaning floors and restocking shelves, the employer could have concluded that 'students needed to learn time-management skills'. ${ }^{52}$

A second immediate benefit to employers may result in cases where the training provided is employer-specific, in that the skills and knowledge acquired are largely if not completely non-transferrable. An example of this second type of benefit was a 12-week training course for casino dealers that was tailored to the casino's specifications and not transferrable to other casinos. $^{53}$

By declining to consider seriously whether a student/intern experience creates an 'immediate advantage' for the employer, even a substantial one, ${ }^{54}$ the primary beneficiary approach ignores a central factor in rooting out employer evasion of the statutory minimum wage. Concern about employer exploitation of students and learners is what led to the crafting of detailed and difficult-to-satisfy exemptions by Congress. It is what led the Supreme Court in Portland Terminal to articulate a narrow exception to those exemptions for an educational experience that 'serves only [the student's] own interest' and where the employer/trainer 'receives no immediate advantage for any work

50 Solis (n 30).

51 Ibid 530-31. These hours included not only providing patient services for which the sanatorium was paid and providing hours of service that counted toward the sanatorium's licensing requirements, but also assisting in growing and selling to the public flowers, produce and wood pallets, and assisting in repairing cars for the public.

${ }_{52} \quad$ Hollins $v$ Regency Corp (n 39) 836-7.

53 Harbourt (n 39). In that setting, unless the students/interns chose to seek jobs with this employer upon completing the course, they would effectively have wasted their time and money on preparation.

54 See Velarde v GW GJ, Inc 914 F 3d 779, 781-5 (2nd Cir, 2019) (for-profit cosmetology school offers ' 1000 -hour course of study' consisting of eight weeks in classroom followed by 22 weeks at 34 unpaid hours per week, performing supervised barbering and hair styling for paying customers and janitorial and clerical work; court recognizes that school gains economic benefit but holds that trainees as primary beneficiaries need not be paid for the 748 hours of course that involves their profit-generating work). 
done by the trainee/students'. ${ }^{55}$ And it is what led the Labor Department to insist that the 'no immediate advantage' factor should be applied in every instance to assess just what the employer is receiving beyond the educational development of a pool of future potential employees.

The primary beneficiary approach also brings two lower-profile changes in emphasis from what had been the law for decades under the Labor Department standard. One involves the ordering of the factors themselves. 'No expectation of compensation from time spent in training' was the last of the six factors in the agency standard, and was rarely a material element in the agency's review. It is now the first-listed factor in the Second Circuit's primary beneficiary approach, signalling to employers that securing this understanding is an important initial step in the process of engaging interns without pay. These understandings can often be preconditioned by the realities of unequal bargaining strength. The Supreme Court has made clear that waivers of the right to compensation are prohibited under the FLSA, ${ }^{56}$ and has warned against employers using superior bargaining power to pressure employees into saying they performed work 'voluntarily' ${ }^{57}$ But bargaining leverage is a foundational element in our labour standards system, including with respect to the FLSA, and this leverage is too often overlooked or ignored when considering the application of that statute and its regulations. Accordingly, one should not be surprised at the proliferation of agreements between interns and employers, 'negotiated' in advance and specifying that services will be performed without pay.

The other change is that the Second Circuit's seven factors are assigned no specific weight and are not even meant to be exclusive. The emphasis on such a wide-ranging ad hoc balancing approach diminishes the attention given to elements that were previously deemed essential - notably that the student/ intern's work does not displace the work of paid employees. The underlying risk is that a set of procedural elements (formal ties to an educational programme and an academic calendar, and a set of pre-existing signatures and understandings between unequal players) has supplanted a substantive focus on whether work is being performed by 'students' that could and should be performed by regular employees and that therefore confers economic benefits on the employer/trainer.

Portland Terminal (n 18) 152-3.

Barrentine v Arkansas-Best Freight System Inc 450 US 728, 740 (1981).

Tony and Susan Alamo Foundation v Secretary of Labor 471 US 290, 302 (1985). 


\subsubsection{Applying the approach to unpaid internships}

There is an almost patronizing class-conscious perspective underlying the circuit courts' new insistence that modern internships 'required to obtain academic degrees and professional certification and licensure in a field are just too different from the short training course offered by the railroad in Portland Terminal'. ${ }^{58}$ The implication that white-collar internships in the knowledge economy are mismatched with FLSA approaches to more blue-collar-orientated vocational training is belied by the fact that, as noted previously, the Labor Department applied its six-factor approach to university and professional educational programmes over many decades. Moreover, this new perspective ignores the reality that university-affiliated internships often differ from apprenticeships and cooperative education arrangements in precisely the ways that legal protections were designed to address. Unpaid internships tend to be characterized by a high level of informality and the absence of well-defined or tightly structured educational or training objectives. Although it may be unfashionable to consider sophisticated college students and graduates as susceptible to being taken advantage of in work settings accompanied by credit or certification, this type of vulnerability is what gave rise to protections accorded to students, learners and apprentices 80 years ago in the FLSA.

Perhaps not surprisingly, circuit courts have begun to extend the primary beneficiary test beyond a relatively formalized educational setting. In Wang $v$ Hearst Corp, the Second Circuit held that a group of unpaid interns working for Hearst Publishing were not employees. As part of its analysis, the court concluded that being assigned to complete repetitive tasks or to take minutes at marketing meetings was beneficial training which need not 'resemble[...] university pedagogy'; that interns did not have to receive university credit as long as such credit was made available; and that although interns did 'complete some work regularly performed by paid employees', this displacement factor favouring the interns was not dispositive, because intern work may 'complement' that of paid employees. ${ }^{59}$

The Portland Terminal mandatory factors place limits on this potentially exploitative arrangement. For instance, the first factor - that 'the training ...

58 Schumann $v$ Collier (n 43) 1211. See also Glatt v Fox Searchlight (n 40) 535 citing 2011 Position Statement on US Internships by National Association of Colleges and Employers.

59877 F 3d 69, 74-5 (2nd Cir, 2017). Wang also makes clear that courts will rely heavily on the interns' clear understanding that they will not be paid: ibid 73 . However, as noted previously, the unequal bargaining power of workers and employers, plus the fact that FLSA rights are not waivable, renders such an 'understanding' and its accompanying 'consent' of dubious persuasive value. 
is similar to that which would be given in a vocational school' - has been understood to require an educational component that extends throughout the internship and delivers substantive content valued beyond the boundaries of the particular workplace, that is, skills and knowledge transferrable to a larger professional or occupational setting. The second factor - 'training for the benefit of the trainees or students' - involves something more targeted to the intern than simply learning the general skills and work habits that accompany any new employee's exposure to a new profession or industry. The third factor - 'no displacement of regular employees' - anticipates close supervision from regular employees, such as a shadowing relationship, rather than allowing interns to perform the company's work independently. ${ }^{60}$ This supervision also is not a licence to assign to interns normal operational tasks that would otherwise be handled by paid workers. ${ }^{61}$

Finally, the fourth Portland Terminal factor - 'no immediate advantage' - has been addressed in detail previously. Although criticized as a harsh bright-line rule, the Labor Department and lower courts recognized that this factor does not preclude minimal productive work by interns if that work is offset by the employer's training and supervision efforts. ${ }^{62}$ Also, under Portland Terminal, there is no balancing among the various factors, no chance that the formalities of interns 'agreeing' not to be paid will outweigh the reality that the employer is receiving immediate benefits from the interns' work and that work is displacing other employees.

By contrast, the primary beneficiary approach emphasizes training analogous to an educational environment, beneficial learning and educational benefits received by the intern. ${ }^{63}$ Yet one would expect interns, like entry-level workers in general, to obtain these educational and training benefits from their work. And interns - again like entry-level employees - will predictably

${ }^{60}$ See Amicus Brief for Secretary of Labor in Glatt (n 40) 13-16 for a discussion of these three factors.

${ }^{61}$ For an illustration of the difference between the Portland Terminal approach and current primary beneficiary law, consider the legal advice offered to employers in a recent news article: 'your role, if you're going to have them as unpaid interns, is to educate them, and it needs to be part of a bigger picture for their development and not just the benefit of your day-to-day operation'. Braden Campbell, 'Interns in the Trump Era: What Employers Need to Know' (Law 360, 29 April 2019) (emphasis added), https://www.law360.com/articles/1154059, accessed 30 March 2021.

62 See Amicus Brief in Glatt (n 40) 16-17, citing Opinion Letters of 5 September 2002 and 13 March 1995. See also Donovan (n 31) 272. The fifth and sixth Portland Terminal factors focus more straightforwardly on students' understandings that they are not entitled to a job after the internship, and that they will not be paid during its operation.

63 See Glatt (n 40) factors 2, 5 and 6. 
be inclined to value these benefits as much or more than the employer values their entry-level services. These comparative balancing assessments, based on subjective judgements, obscure the underlying objective issue that matters from the standpoint of the FLSA: whether the interns are performing services that replace or displace what paid employees would offer, and that confer an immediate economic advantage on the employer.

\subsection{UNPAID INTERNS AND PUBLIC POLICY}

From 2014 to 2018, between 53 and 60 per cent of college seniors completed an internship during their time at school. ${ }^{64}$ In the same five-year period, between 43 and 46 per cent of these internships were unpaid. Although many internships involve service to non-profits or government agencies, over half of seniors' college internship experiences were with for-profits during this five-year period. ${ }^{65}$

Internships also have become more regular features of business school and law school education. There is a steady demand among employers for business student internships; the majority of business interns work at for-profit enterprises and nearly half of them are unpaid. ${ }^{66}$ The law school numbers are not as well researched, ${ }^{67}$ but it is clear that many law schools sponsor unpaid internships with for-profit enterprises for academic credit. ${ }^{68}$ While these field placements may now be paid and receive academic credit (pursuant to a 2016 change in American Bar Association guidance), one consequence has been

${ }^{64}$ National Association of Colleges and Employers (NACE), 2018 Student Survey Report: Attitudes and Preferences of Bachelor's Degree Students (NACE 2018) 20.

65 Ibid. The proportion of total internships at for-profits was 55 per cent, 53 per cent, 55 per cent, 53 per cent and 47 per cent for the years 2014-18: ibid 21. In 2018, internships at non-profits were 32 per cent of the total, and at government agencies 21 per cent. The numbers for 2018 are for all seniors, not just graduating seniors.

66 Ann Marie Johnson and David L Baker, 'Business Student Internships: A Pathway to Resolving the Perils of Unpaid Placements' (2018) 10 Bus Educ Innovation J 41, 43, 45 .

67 In a recent survey of applied legal education, the median percentage of students who participated in a field placement course before graduation was 51-5 per cent: Robert R Kuehn and David A Santacroce, The 2016-17 Survey of Applied Legal Education (CSALE 2017) 12.

68 Melissa Hart, 'Internships as Invisible Labor' (2014) 18 Employee Rts \& Empl Poly J 141, 150. Four years after Hart's survey, the American Bar Association (ABA) lifted its ban on law students receiving both pay and academic credit for internships: Karen Sloan, 'ABA Approves Pay for Law Students' For-Credit Externships' (Law. com, 8 August 2016), https://www.law.com/sites/almstaff/2016/08/08/aba-approves -pay-for-law-students-for-credit-externships/?slreturn=20200829021021, accessed 30 March 2021. 
a trend toward more internships at for-profit firms that are minimally supervised as regards education. These for-profit enterprises notably include companies in the media and fashion industries as well as private law firms; they all must provide some form of 'written assurance that the students will receive an educational experience'. ${ }^{69}$

\subsubsection{Policy Arguments Supporting Internships, with Caveats}

In the current professional world, internships are perceived as generally beneficial to students and employers as well as to educational institutions. A recent research paper describes internships as 'provid[ing] students with valuable professional experience and networks [and] giv[ing] employers a steady stream of new talent with fresh ideas from academia'; in addition, they 'enable educators to create venues for students to translate academic knowledge to real-world situations' ${ }^{70}$ From an optimal standpoint, interns enrolled as undergraduates, business students or law students acquire a level of on-the-job training through closely observing the operations of successful enterprises and individual mentors within those enterprises. In addition, interns' networking opportunities forge connections that may lead to job opportunities in the future. And by listing the internship on their curriculum vitae $(\mathrm{CV})$, students demonstrate to possible future employers their commitment to a field, as well as their capacity to participate in the relevant professional or occupational culture. ${ }^{71}$

There is debate about how far interns realize these benefits in practice. Ross Perlin is perhaps the leading sceptic. In his book examining the experiences of interns across the United States, Perlin concludes that 'focused training and mentoring are vanishingly rare' and that 'the sheer scale of the internship arms race has made the raw credential unremarkable, a box to be checked ... [its] power is largely negative - it seems risky not to have done one, it teaches you what not to do'. ${ }^{72}$ Perlin acknowledges that some internships meet the idealized

69 Letter from M Patricia Smith, Solicitor of Labor, to Laurel G Bellows, Immediate Past President of American Bar Association, 12 September 2013.

70 Matthew T Hora, Zi Chen, Emily Parrott and Pa Her, 'Problematizing College Internships: Exploring Issues with Access, Program Design, and Developmental Outcomes in Three U.S. Colleges' (2019) Wisc Center for Educ Research Working Paper No 2019-1.

71 Ibid. See also NACE (n 64). Among the results reported are: 73 per cent of students were satisfied or very satisfied with the experience, and they reported improved development of a range of job-related competencies (such as work ethic, teamwork collaboration, communication skills, problem-solving). At the same time, nearly 60 per cent expressed dissatisfaction with pay level or status, and 25 per cent of time was spent on administrative, clerical or non-essential functions.

72 Perlin (n 2) xv, 203-4 (original emphases). 
standards referred to above, but contends that on the whole they fall far short of meeting that description: 'As education, they pale in comparison to our schools. As training to work, they compare unfavourably with apprenticeships. As a form of work, they are often a disappointment, and sometimes a rank injustice. ${ }^{73}$

Perlin is hardly the only sceptic about the positive effects of internships. Studies of internships in the United Kingdom, Europe and Australia identify a range of concerns about internships being deficient in learning content as well as working conditions and employment outcomes. ${ }^{74}$ Overall, results in the United States setting might be characterized as positive though mixed in terms of educational benefits and employment prospects. Perhaps representative is one study concluding that students derived greater value from internship programmes when the programmes were highly structured, integrated into their programme of study, and clearly related to their interests and career goals. ${ }^{75}$

\subsubsection{Paid versus unpaid internships}

Accepting for the sake of argument that the enormous increase in internships over the past decade or more reflects at least some positive results, a key question is whether the benefits and advantages are comparable for paid and unpaid internships at for-profit companies. The quantitative answer seems to be no - paid internships offer more in the way of employment prospects and entry-level compensation than do unpaid internships.

Recent research indicates that, of the sizeable number of undergraduate students who want an internship but are unable to pursue one, over a quarter report insufficient pay as a factor and more than half invoke the need to work at their current paid job. ${ }^{76}$ Moreover, for those who do gain access, being in a paid internship is more likely to lead to employment than being in an unpaid internship. A 2015 National Association of Colleges and Employers (NACE) study found that paid internships with private for-profit companies result in a substantially higher rate of offers of permanent employment (72.2 per cent versus 43.9 per cent). ${ }^{77}$ Also, median starting salaries for students following

\footnotetext{
73 Ibid 205.

74 See eg Chapter 2 in this volume; Paula McDonald, 'Open Market Internships: What Do Intermediaries Offer?' (2020) 33 J Educ \& Work 33, 35-6.

75 Michael Hergert, 'Student Perceptions of the Value of Internships in Business Education' (2009) 2 Am J Bus Educ 9, discussed in Matthew T. Hora, Matthew Wolfgram and Samantha Thompson, 'What Do We Know about the Impact of Internships on Student Outcomes? Results from a Preliminary Review of the Scholarly and Practitioner Literatures' (2017) CCWT-WCER Research Brief No 2.

76 Hora and others, 'Problematizing College Internships' (n 70) 11.

77 NACE, 'Paid Interns/Co-Ops See Greater Offer Rates and Salary Offers than Their Unpaid Classmates' (NACE, 23 March 2016), http://www.naceweb.org/job
} 
paid internships at for-profits are more than 50 per cent higher than median starting salaries following unpaid internships in the same settings. ${ }^{78}$

A more recent NACE study supports the continued existence of a substantial pay differential for first-position salaries between college graduates with paid and unpaid internships; it further found that students with paid internships attained jobs more quickly than those whose internships were unpaid. ${ }^{79}$ Another study also showed that participation in unpaid internships was correlated with a longer job-search process upon graduation. ${ }^{80}$ In summary, available data indicates that students seeking internships often cannot afford one if it is not paid and, while students accepting unpaid internships at for-profits may do better in the job market than those with no internships at all, ${ }^{81}$ they do not do nearly as well in securing jobs or decent starting salaries as their classmates who had paid internships.

\subsubsection{Nature of the unpaid intern population}

The most extensive survey data on the personal and curricular backgrounds of unpaid college interns dates from $2010 .{ }^{82}$ Results from this study indicate that unpaid interns are much more likely to be women than men. ${ }^{83}$ Among students in unpaid internships, those from high-income families were more likely to be at for-profit companies, whereas those from lower-income settings tended to do unpaid internships with non-profit organizations. Paid interns from

-market/internships/paid-interns-co-ops-see-greater-offer-rates-and-salary-offers-than -their-unpaid-classmates/, accessed 30 March 2021 (citing 2015 Student Survey). There is a differential across all sectors, not just for-profit, but the difference is considerably smaller for internships in the non-profit (51.7 per cent versus 41.5 per cent), state/local government ( 50.5 per cent versus 33.8 per cent), and federal government sectors (61.9 per cent versus 50 per cent). See ibid.

78 Ibid.

79 Desalina Guarise and James Kostenblatt, Unpaid Internships and the Career Success of Liberal Arts Undergraduates (NACE 2018) 6.

80 Andrew Crain, Understanding the Impact of Unpaid Internships on College Student Career Development and Employment Outcomes (NACE 2016) 18, http:// www.naceweb.org/uploadedfiles/files/2016/guide/the-impact-of-unpaid-internships -on-career-development.pdf, accessed 30 March 2021.

${ }_{81}$ According to Guarise and Kostenblatt (n 79) 6, previous NACE studies had found no correlation between unpaid internships and job offers prior to graduation, but their study found that those with unpaid internships found jobs more quickly and had higher initial salaries than those with no internships.

82 Phil Gardner, The Debate over Unpaid College Internships (Intern Bridge 2010). The online survey was completed by 27335 students at 234 colleges and universities in the US: ibid 5.

83 Ibid 6 (77 per cent of unpaid interns were women). 
high-income families were more likely to be interning at for-profits than were lower-income students. ${ }^{84}$

Unpaid interns include a greater share of students majoring in education, social sciences, health sciences, communications, and arts and humanities, as compared with those majoring in engineering and computer sciences, biological and physical sciences, or agriculture. ${ }^{85}$ More recent data indicates that the curricular patterns continue to apply, as does the strong tendency for unpaid interns to be female. ${ }^{86}$

Companies in the utilities, transportation and manufacturing sectors were highly unlikely to offer unpaid internships. ${ }^{87}$ By contrast, employers in the arts, entertainment and broadcasting sectors offered a substantial majority of their internships as unpaid. ${ }^{88}$ The frequency of unpaid internships in the arts, a sector characterized by small firms that might find a minimum wage requirement onerous, raises the possibility that students will have less access to on-the-job experience if internships in this sector must be paid. However, the entertainment and broadcast industries include many large companies that can presumably well afford to pay an internship wage.

\subsubsection{Synergies with educational institutions}

Educational institutions benefit from tuition payments that accompany outsourcing of experiential learning. This outsourcing can be minimized for internships that feature sufficient educational control including extended classroom supervision. ${ }^{89}$ However, often these internships are characterized by looser educational connections and weak to non-existent academic supervision..$^{90}$

At law schools, there is pressure, caused by ABA accreditation standards, to provide substantial experiential opportunities. ${ }^{91}$ Although the ABA has changed its standards so that law school-approved internships can also be paid, anecdotal data indicates that a sizeable number of law schools permit unpaid internships for credit in corporate counsel offices involving media and fashion companies, among others. Of 12 law schools nationally responding to listserv questions posed by a Fordham law colleague in June 2019, 11 allow unpaid

\footnotetext{
Ibid 7.

Ibid 6.

Andrew Crain, Exploring the Implications of Unpaid Internships (NACE 2016).

Gardner (n 82) 7 (17 per cent of internships in this group were unpaid).

Ibid (68 per cent of internships for this group were unpaid).

See Hora and others, 'What Do We Know' (n 75).

90 Perlin (n 2) ch 5; Hora and others, 'Problematizing College Internships' (n 70)

91 Hora and others, 'What Do We Know' (n 75) 150.
}

14. 
in-house placements at for-profit firms, while only one does not. ${ }^{92}$ Within the New York area, six out of seven law schools contacted (in a separate ad hoc survey) allow internship placements with for-profit firms, including law firms. Responses suggest that between ten and twenty law students at each school participate each semester; most are unpaid for-credit arrangements. ${ }^{93}$

More broadly, law firms want experience-ready entry-level attorneys, and are not willing to pay for the experience as they formerly did when they could train first-year associates at clients' expense. Law clinics are the principal way that law schools have responded to the changing priorities of the profession, but these clinics are costly and labour intensive. Internships or externships with loosely supervised academic credit can thus provide both employers and law schools with advantages.

\subsubsection{Costs Associated with an Unpaid Intern Population}

\subsubsection{Lack of protections under anti-discrimination laws}

Unpaid internships leave students vulnerable to being discriminated against based on their sex, race, age or disability status. Because the relevant federal anti-discrimination statutes protect only 'employees', that is, those who work for an employer for some form of compensation, unpaid interns generally do not qualify. In the often cited case of O'Connor $v$ Davis, ${ }^{4}{ }^{4}$ a college student was sexually harassed by a psychiatrist at the mental hospital where she was serving her senior-year unpaid internship. She sued the hospital under Title VII but the district court dismissed her claim. In holding that O'Connor was not an employee under the statute or under a common law agency analysis, the court emphasized that 'the preliminary question of remuneration is dispositive in this case. It is uncontested that O'Connor received from [the hospital] no salary or other wages, and no employee benefits'. ${ }^{95}$

Absent any federal law protection, a minority of states have attempted to address this gap. Legislatures in ten states or localities now include unpaid

92 The one school that did not allow unpaid internships gave as its reason: 'in order to avoid potential Fair Labor Standards Act violations'. Results on file with author.

93 Results on file with author.

$94 \quad 126$ F 3d 112 (2nd Cir, 1997).

95 Ibid 116. The $O^{\prime}$ Connor decision has been cited in 175 other cases. The same threshold problem identified under $O^{\prime}$ Connor regarding Title VII protection also exists under the Americans with Disabilities Act and the Age Discrimination in Employment Act. If interns receive a sufficient level of remuneration not in the form of wages, they may be protected as employees under federal law. See United States $v$ City of New York $359 \mathrm{~F} 3 \mathrm{~d}$ 83, 91-7 (2nd Cir, 2004). For an intern population that is overwhelmingly female and either undergraduate or postgraduate (in law or business), the major gap in protection involves sexual harassment in the workplace. 
interns within the scope of their anti-discrimination protections. ${ }^{96}$ At least three of these state statutes define 'intern' or 'unpaid intern' in language that tracks the Labor Department's former six-part test. ${ }^{97}$ Some courts have narrowly construed the language or purpose of these laws ${ }^{98}$ while others have applied them more generously. ${ }^{99}$ Still, the great majority of states have no law protecting unpaid interns against discrimination, including sexual or racial harassment.

\subsubsection{Social mobility consequences}

As noted previously, students with more serious financial needs often cannot afford unpaid internships. This can exacerbate the existing lack of equal access to the professions. It seems that wealthier students reap a greater share of networking and $\mathrm{CV}$-enhancing benefits that accrue to some extent even from unpaid internships with large for-profit companies in the entertainment, broadcasting or fashion industries. These economic disparity effects also are likely to entail disparate impacts related to race. Insofar as unpaid internships are a gateway to higher-skill job markets, the well-documented gap in economic opportunity faced by African-American and Hispanic youth ${ }^{100}$ is reinforced for populations with college or professional degree credentials.

Moreover, the great majority of unpaid interns being female suggests that women either have, or perceive they have, less bargaining power than do men. The distinctly gendered aspect of unpaid internships exacerbates larger gender-based disparities in the labour market. Similar gap-widening effects of unpaid internships have been noted in studies from the United Kingdom, Australia and other countries. ${ }^{101}$

96 See laws in Washington, DC, Oregon, New York City, New York State, California, Texas, Maryland (which covers disability discrimination as well), Connecticut, Illinois and Delaware.

${ }_{97}$ Ore Rev Stat s 659A.350 (enacted 2013); Tex Lab Code s 21.1065 (enacted 2015); Illinois also uses the six-part DOL test in its definition of interns, although the statute is limited to sexual harassment: ILCS 5/2-101. New York and Maryland define 'intern' using the DOL test but omit the 'immediate advantage' factor: see NY CLS Exec s 296-c (2014); Maryland State Gov't Code s 20-610 (effective 2015).

98 Vejo v Portland Pub Schls 204 F Supp 3d 1149, 1169 (D Ore, 2016); Hughes $v$ Twentieth Century Fox 304 F Supp 3d 429 (SD NY, 2018); Commission on Human Rights v Echo Hose Ambulance 140 A 3d 190 (Conn, 2016).

99 Hirst $v$ City of Oceanside 236 Cal App 4th 774, 783-90 (Cal App, 2015).

100 See generally Emily Badger and others, 'Extensive Data Shows Punishing Reach of Racism for Black Boys' NY Times (New York, 19 March 2018); Ronald Brownstein, 'The Challenge of Educational Inequality' The Atlantic (Boston, MA, 19 May 2016).

101 See Chapter 2 in this volume; McDonald (n 74) 36. 


\subsubsection{Displacing paid employment}

There has also been deep concern expressed at the international level that unpaid or even low-paid internships may displace paid employment and prevent experienced and trained workers from entering or continuing in the labour market. ${ }^{102}$ One aspect of research in the United States not pursued by employers or universities is how many full-time entry-level jobs are lost because interns are doing this work. Although the issue of job displacement is often framed in terms of unpaid placements at the lower end of the job market, the proliferation of undergraduate and law school internships (unpaid but also paid) at for-profit firms raises the issue in a white-collar knowledge-economy context.

It is not clear, for example, to what extent entry-level attorneys may be replaced by a series of renewable unpaid (or even paid) third-year law students serving as interns. Intriguingly, when the ABA abandoned its long-standing rule against awarding academic credit for paid internships, thereby substantially increasing the attraction of for-profit firm placements, the change was opposed by the Clinical Legal Education Association (CLEA). As part of its concern that this would adversely affect the quality and diversity of law school field placements (public interest and public service field placements cannot afford to pay), the CLEA indicated risks of exploitation and abuse related to the job market:

Effective educational practice requires that ... field placement supervisors serve as teachers and mentors, not as employers ... When work is compensated, the employer is compelled to make its own interests the primary focus of the supervisor-student relationship. The supervisor of a paid employee has an obligation to justify the compensation ... Paid employment is a contract between employer and employee, to which the law school is not a party. ${ }^{103}$

Notwithstanding CLEA's concerns, an increasing number of law schools are inclined to utilize these loosely supervised internships with for-profit employers. The possibility that large media or fashion companies may engage two or three interns each semester, effectively displacing the need for an entry-level attorney, deserves more research attention.

Stepping back, there are larger normative implications of the widespread use of unpaid internships as a 'check the box' aspect of career preparation. Millions of university students and graduates now enter higher-skilled labour markets where working without being compensated is both expected and

102 See Chapter 2 in this volume.

103 Clinical Legal Education Association, Comment on Interpretation 305-2 and the Question of Paid Externships in Law Schools (CLEA 2015). 
accepted without complaint. These entry-point perceptions (shared by countless others who wish they could secure these internships) impact the attitudes and aspirations of those same individuals as they graduate from university and move into the paid labour market. Such a cultural change is difficult to quantify, but it seems possible that pervasive acceptance of unpaid internships increases readiness to accept work as an independent contractor with no expectation of being paid for hours worked; or willingness to work long hours for no pay when holding jobs as non-exempt employees under the FLSA. Comparable shifts in perception or attitude may also be manifested when these individuals become managers and their expectations of workers they supervise - especially higher-skilled or professional workers - are that working for many months without pay is a valuable rite of passage into the relevant labour market. In summary, the institutionalized use of unpaid internships potentially creates and embeds norms that tolerate wider non-payment of work.

\subsection{CONCLUSION}

It is difficult to envision a return to stronger intern protections under the FLSA in the immediate future. Although the Supreme Court has not addressed the tension between Portland Terminal and the appeals courts' endorsement of a primary beneficiary test, the Supreme Court's recent FLSA jurisprudence does not suggest an especially worker-protective approach. ${ }^{104}$ There also is little prospect of legislative correction at the federal level; Congress remains gridlocked on various labour standards issues, including its inability to raise the federal minimum wage under the FLSA since 2007.

Still, given the shrinking of protection for millions of unpaid interns, several possible responses at the federal level are worth considering. First, the Labor Department could develop a guidance aimed specifically at for-profit institutions and employers that wish to sponsor internships. The strong presumption should be that for-profit employers will pay the minimum wage to interns or individuals in intern-type positions. At the very least, for-profit employers should not be able to assign unpaid interns tasks or duties that displace regular employees. Nor should unpaid interns perform activities that provide the employer with an immediate economic advantage.

Second, the Labor Department could encourage educational institutions to demonstrate their provision of meaningful protections for student interns.

104 See Encino Motorcars, LLC v Navarro 138 S Ct 1134 (2018); Integrity Staffing Solutions v Busk 574 US 27 (2014); Sandifer v US Steel 571 US 220 (2014); Genesis Healthcare Corp v Symczyk 569 US 66 (2013); Christopher v SmithKline Beecham 567 US 142 (2012). 
Detailed compliance records, to be completed regularly by responsible academic faculty, should attest to the learning objectives of particular fieldwork experiences, the metrics for assessing whether those objectives are being met and the implementation of a regular review mechanism to assess the interns' working conditions.

Finally, the department could strongly encourage academic credit to be part of approved internships. As part of this academic credit experience, the department should require close and continuing employer supervision, and prohibit any displacement of regular employees. 